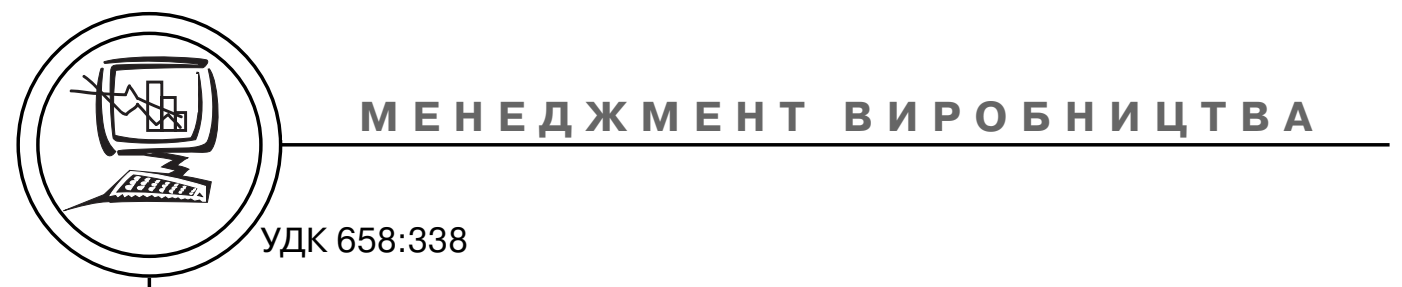

() А. В. Кваско, канд. екон. наук, доцент, КПІ ім. Ігоря Сікорського, Київ, Україна

\title{
МЕТОДИ ТА ПОКАЗНИКИ ОЦІНКИ РІВНЯ РОЗВИТКУ ВИДАВНИЧО-ПОЛІГРАФІЧНИХ ПІДПРИЕМСТВ
}

\author{
У статті розглянуто методи оцінки рівня розвитку \\ підприємств, охарактеризовано групи показників \\ (індикаторів), що використовуються при оцінці розвитку \\ суб'єктів господарювання та сформовано систему \\ показників оцінки рівня розвитку видавничо-поліграфічних \\ підприємств з урахуванням галузевих особливостей.
}

Ключові слова: розвиток; оцінювання розвитку; конкурентоспроможність; потенціал; індикатор; система показників; видавничо-поліграфічні підприємства.

\section{Постановка проблеми}

В сучасних умовах господарювання підприємства для забезпечення свого місця на ринку або його певному сегменті повинні не лише пристосовуватись до мінливих умов зовнішнього середовища, а й намагатись забезпечити його постійний розвиток. Саме управління розвитком підприємства, на нашу думку, має стати обов'язковою складовою системи управління будьякого підприємства. Причому акцент, в даному випадку, ми робимо саме на розвиток як рух, в результаті якого можна сформувати нові риси чи характеристики виробничо-економічної системи, або процес, наслідком якого є зростання можливостей суб'єкту господарювання щодо досягнення поставлених цілей, задоволення своїх бажань та очікувань інших суб'єктів ринку, зокрема споживачів. Одним з етапів ефективного управління розвит- ком підприємства є правильна і об'єктивна оцінка рівня його розвитку. Вона також $є$ необхідною умовою ефективного формування стратегії розвитку суб'єкту господарювання. Тому питання дослідження методологічних підходів та вибір найоптимальнішого з них $є$ актуальним у сучасних умовах.

\section{Аналіз попередніх} досліджень

Проблемам розвитку підприємств присвячені праці багатьох вчених, таких як В. С. Пономаренко, О. М. Тридід, М. О. Кизим [1], О. В. Раєвнєва [2], Г. О. Швиданенко, К. С. Бойченко [3, 4], Р. В. Фещур, В. Ю. Самуляк $[5,6]$, Ю. С. Погорелов [7], М. П. Тимощук [8] та інших. В них розглянуто як теоретико-методологічні аспекти розвитку, його види, так і питання управління розвитком та, зокрема, методи його оцінювання.

Сьогодні існує багато підходів до оцінки рівня розвитку підпри-

(C) $2019 \mathrm{p}$. 
ємства. Така багатоваріантність вибору, з одного боку, дає можливість використати саме ті методи, які найбільш доцільні для даного підприємства за конкретних умов, але 3 іншого ускладнює процеси оцінювання та порівняння результатів через відсутність єдиної системи показників. Варто зазначити, що значна частина методів заснована на дослідженні результативності окремих напрямів роботи суб'єкту господарювання, в результаті узагальнення яких і формується висновок про розвиток підприємства.

Так, Самуляк В. Ю. та Фещур Р. В. групують науково-методичні підходи до оцінки розвитку організації за спрямованістю аналізу окремих показників, а саме: конкурентоздатність, етап життєвого циклу підприємства, інтегральний показник розвитку, реалізація потенціалу [6, С. 628]. Аналогічну думку висловлює і Жилінська Л. О., яка уточнює назви цих підходів: «оцінка на основі рівня конкурентоздатності та порівняння конкурентних позицій господарюючого суб'єкта з позиціями інших на ринку; оцінка на основі визначення та аналізу складових потенціалу розвитку досліджуваного підприємства; оцінка на основі аналізу з точки зору фази розвитку підприємства» [9, С. 104]. Бойченко К. С. поділяє всі підходи до оцінки розвитку організації на методи якісної та кількісної оцінки [4, С. 19].

Ряд методів ґрунтуються на визначення сильних і слабких сторін підприємства, переваг над іншими суб'єктами господарювання та виявленні на основі цього його потенційних можливостей.
Інші методи дозволяють виявити тенденції та напрями розвитку підприємства, враховуючи тільки загальні результати роботи організації. Ще одна з груп методів хоча й базується на аналізі показників за всіма напрямами діяльності підприємства, що передбачає обробку великого масиву даних, а це потребує не лише часу, а й правильного узагальнення результатів. Водночас існує необхідність обґрунтованого вибору та адаптації методів оцінки розвитку виробничо-економічних систем до галузевих особливостей (специфіки) господарювання підприємств видавничополіграфічної галузі.

\section{Мета роботи}

Дослідження економічного інструментарію та обґрунтування підходу до формування системи показників оцінювання рівня розвитку видавничо-поліграфічних підприємств.

\section{Результати проведених досліджень}

Аналіз наукових напрацювань з досліджуваного питання свідчить про існування різних методів, моделей та алгоритмів оцінки розвитку підприємства, що може бути пов'язано з інтерпретацією даного поняття. Ми погоджуємось з О. В. Раєвнєвою, яка виділила три підходи до розуміння «розвитку», а саме: виділення та вивчення властивостей систем, що розвиваються; розгляд категорії як порівняльної характеристики об'єкту; формування трактувань даного поняття [2, С. 108]. Один з підходів пов'язаний зі спрямованістю, незворотністю та унікальністю процесів змін системи у 
просторі і часі. А підприємство і $€$ тою самою відкритою системою. За другого підходу увага зосереджується на формуванні нової відкритої системи зі своєю траєкторією розвитку в результаті трансформації існуючої системи в просторі і часі, що, в свою чергу, є наслідком зміни цілей її функціонування. Третій підхід також пов'язаний з формування нової відкритої системи, проте акцентує увагу на якісній зміні складу, структури і способу функціонування цієї системи для досягнення відповідних цілей.

Дослідження наукової літератури дозволило виділити дві групи підходів до оцінювання ефективності управління розвитком суб'єктів господарювання: оцінювання на основі інтегрального показника ефективності та оцінювання на основі системи критеріїв і показників. В ці групи вільно вписуються і найбільш відомі напрями оцінки рівня розвитку: на основі показників конкурентоспроможності, за фазою розвитку компанії, на основі інтегрального показника, за результатами комплексного таксономічного аналізу, на основі дослідження потенціалу. Варто відзначити, що методи, які використовуються всередині цих напрямів можуть передбачати і зведення результатів до узагальнюючого показника (наприклад, індексу), і базуватись на системи критеріїв та показників.

Так, більшість методів оцінки на основі показників конкурентоспроможності поєднують аналіз внутрішнього стану підприємства та оцінку його конкурентних позицій на певний момент часу, а це означає, що зроблені вис- новки будуть актуальні протягом незначного часового періоду. Інтегральний показник конкурентоспроможності та діагностика банкрутства $€$ інструментами діагностики за фазою розвитку компанії через визначення показника конкурентний статус підприємства. Інтегральний показник оцінки стану розвитку підприємства враховує вплив багатьох чинників за допомогою методу таксономії. Система показників, на основі якої визначається таксономічний інтегральний показник, дуже різноманітна. Так модель Хофера-Шендела включає такі показники як: різноманітність асортименту виробів, відносну частку ринку, ефективність системи розподілу, виробничі потужності, обсяги продукту, конкурентоспроможність цін, репутацію тощо [10, С. 85]. Таксономія комплексної оцінки розвитку за Ю. Б. Івановим, О. М. Тищенко, Н. А. Дробитько, О. С. Абрамовою включає техніко-технологічні показники та ті, що характеризують кадрові ресурси, ресурси фінансового стану і фінансових результатів, однак вони нехтують зовнішніми характеристиками, зокрема часткою ринку та ціною реалізації [11]. На основі складових внутрішнього середовища (виробнича діяльність, фінансовий стан та сфера праці) пропонує визначати таксономічний інтегральний показник О. Раєвнєва [2]. В основі оцінки рівня розвитку підприємства як ступеня реалізації потенціалу також лежить розрахунок інтегрального показника на базі одиничних і групових критеріїв аналізу потенціалу. Найвідомішими підходами до оцінки потенціалу є ресур- 
сний, структурний та цільовий. Перший з них використовує показники, що характеризують наявність та ефективність використання ресурсів. Другий орієнтується на визначення раціональної структури потенціалу. Третій підхід оцінює відповідність наявного потенціалу досягненню поставлених цілей. Хоча оцінка потенціалу і потребує наявності великої кількості інформації та часу на її обробку, проте дозволяє оцінити рівень перспектив розвитку суб'єкту господарювання.

Проведені дослідження показали, що основним питанням є вибір не методу, а системи показників, на основі яких і відбуватиметься оцінка. Найбільш типові набори показників подано в табл. 1. Для більшого увиразнення послідовність подання основних груп показників досліджуваних систем була змінена порівняно 3 авторською (послідовність врахування групових оцінок в інтегральному показнику). Отже, якщо перелік показників за методом ефективної конкуренції вважати базовим, то В. Ф. Оберемчук не лише розширила цей перелік майже вдвічі, а й додала для оцінки такі групи як імідж підприємства, показники соціальної ефективності та екологічність виробництва. Крім того ряд показників, що присутні в обох системах, можуть відноситись до різних груп оцінки, зокрема, фондовіддача, продуктивність праці. Системи показників за Р. В. Фещур і В. Ю.Самуляк та К. С. Бойченко є дуже подібними, але також фондовіддача в одному випадку характеризує економічну ефективність, а в іншому $€$ показником використання ресурсів.
Ряд дослідників [14, С. 76] спрощують подібні системи показників до трьох компонент (груп), кожна з яких містить три індикатори, а саме:

1) ресурсна компонента: матеріалоємність операційної діяльності, фондоємність операційної діяльності, зарплатоємність операційної діяльності;

2) процесна компонента: витрати на 1 грн виробленої продукції, рівень зносу основних фондів, продуктивність праці персоналу;

3) результативна компонента: доход від операційної діяльності, рентабельність операційної діяльності, прибуток від операційної діяльності.

За методикою BSC (збалансованих показників) [15] групування показників пов' язано з проекцією розвитку організації, а саме з якої позиції ведеться дослідження. Так внутрішня проекція розвитку підприємств означає розвиток з позиції самого підприємства і передбачає такий набір показників: кількість нових клієнтів у цільових сегментах ринку; темпи зростання попиту на окремих регіональних сегментах; кошти, спрямовані на формування потреб споживачів; кількість робочих днів між отриманням замовлення та його виконанням. Розвиток з позиції інвесторів характеризує фінансову проекцію розвитку підприємства і включає такий перелік показників: темпи зростання обсягів продаж; рентабельність капіталу підприємства; величину позитивного грошового потоку; рентабельність продукції підприємства. За маркетинговою проекцією розвитку (розвиток з позицій клієнта) слід 


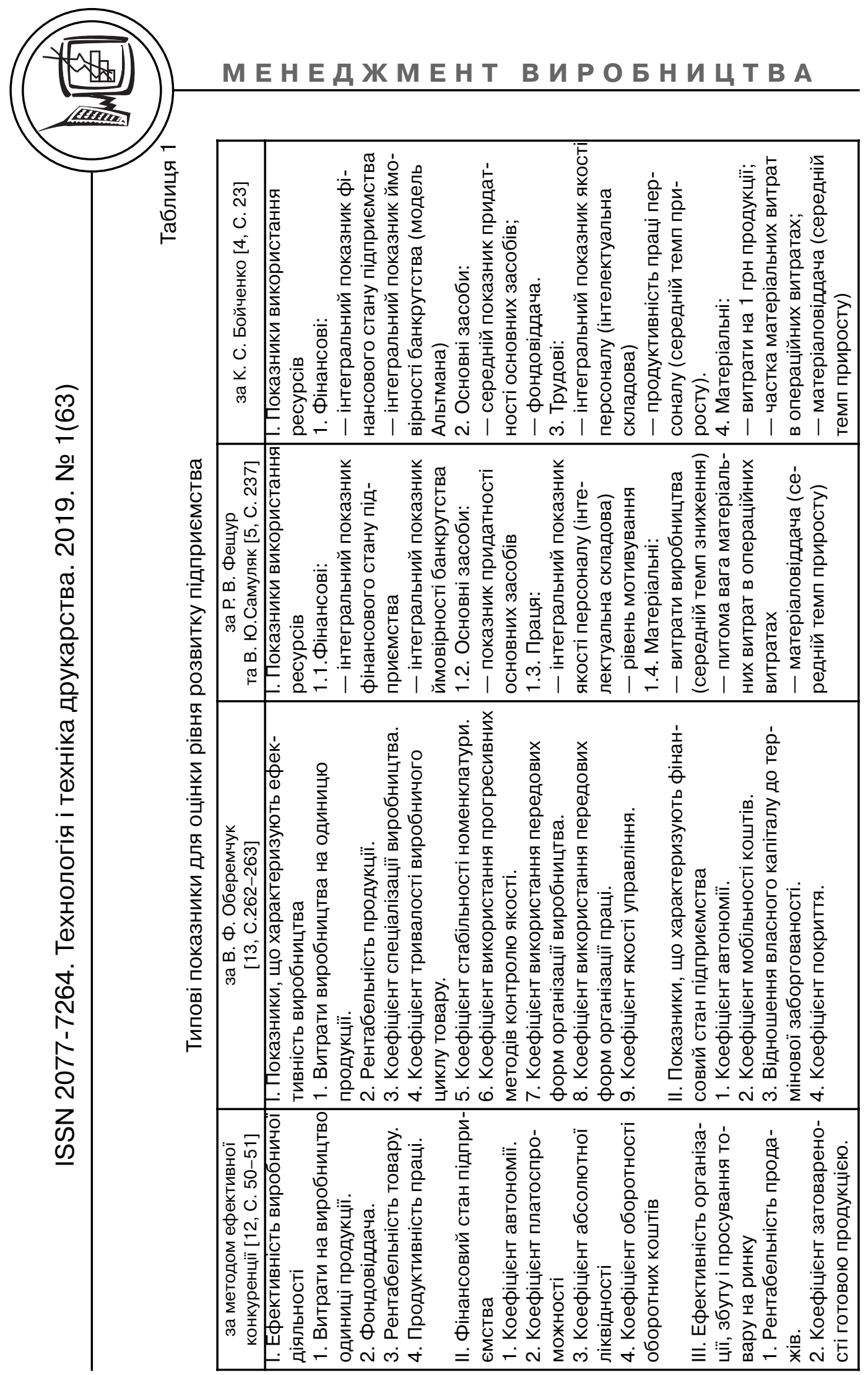




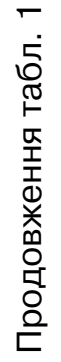

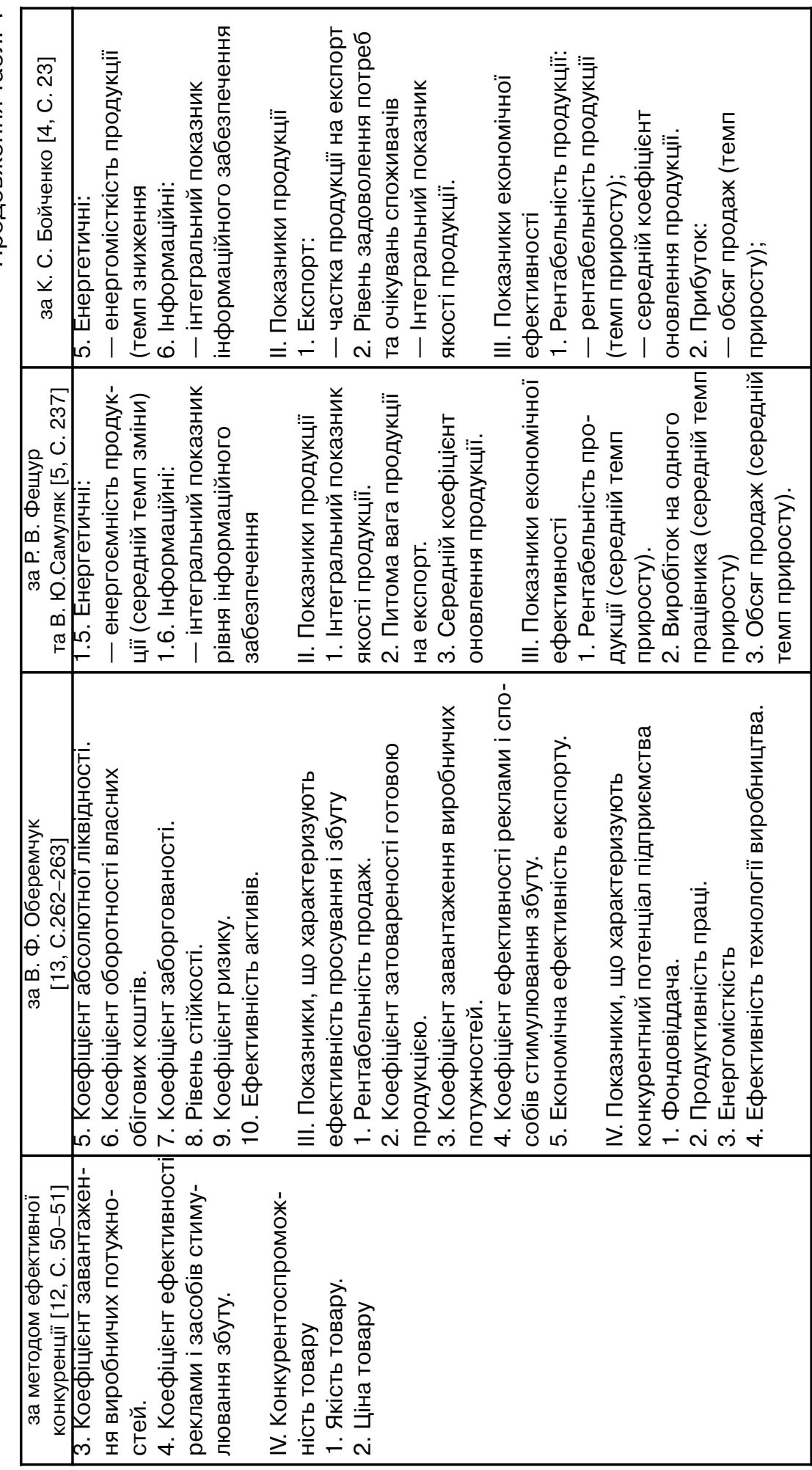




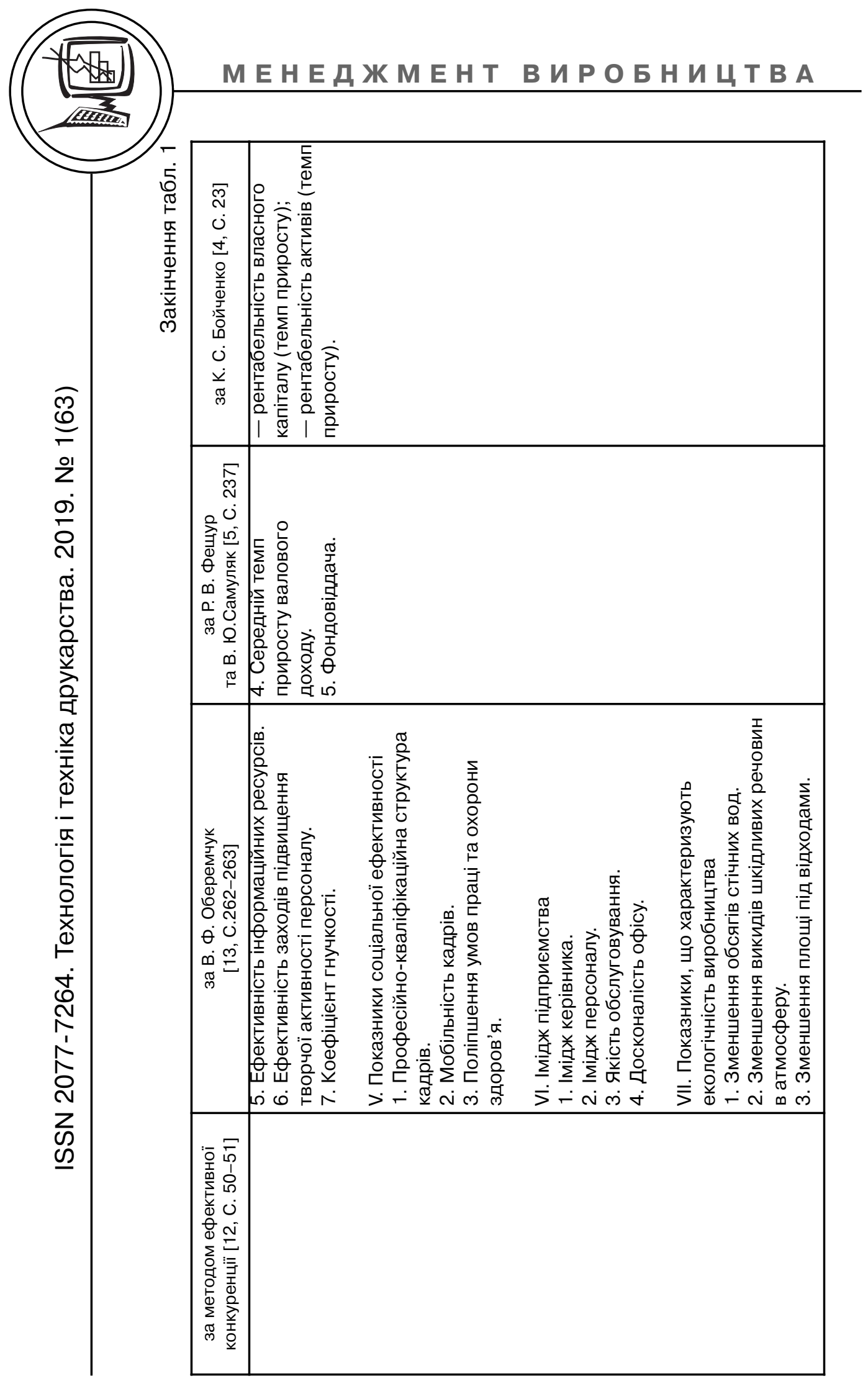

64 
оцінити покращення співвідношення «ціна/якість»; частку нових товарів (послуг) в загальному обсязі продаж; частку продажу постійним клієнтам; ринкову частку основного постачальника. Складова розвитку з позицій гнучкості та перспектив підприємства включає два показники індекс задоволення співробітників роботою та кількість пропозицій щодо удосконалення окремих бізнес-процесів в розрахунку на одного співробітника.

Видавнича справа $€$ певною формою масової комунікації. Робота видавництв, з соціальної точки зору, спрямована на забезпечення інформаційних потреб суспільства. Поліграфічні підприємства, крім тиражування періодичних і неперіодичних видань, забезпечують виконання поліграфічних робіт для різних галузей економіки. Для видавничо-поліграфічних підприємств пропонується формувати групи показників (індикаторів) оцінки їх розвитку за напрямами оцінки основних видів бізнес-процесів (виробничі, фінансові, маркетингові) з урахуванням особливостей їх господарської діяльності (табл. 2).

Для зведення часткових показників до узагальнюючого (інтегрального) показника варто обрати один з двох методів: метод балів або середньої геометричної. В першому випадку матриця оціночних показників перетворюється у матрицю балів, на основі якої й визначається узагальнюючий показник. Другий метод передбачає розрахунок групових коефіцієнтів, а на їх основі визначається інтегральний коефіцієнт як середня геометрична з групових коефіцієнтів. Для отримання більш точного результату можна вводити вагові коефіцієнти, які визначаються методом попарних порівнянь.

\section{Висновки}

Аналіз наукової літератури щодо питань оцінки рівня розвитку підприємства засвідчив, що більшість методів оцінки базується на системі показників (індикаторів), які можуть включати кількісні та якісні показники, фінансові й нефінансові, показники ефективності використання ресурсів та показники, що характеризують положення підприємства на ринку. На основі систематизації існуючих підходів до оцінки розвитку підприємств та з урахуванням специфіки діяльності підприємств видавничополіграфічної галузі було запропоновано систему показників оцінювання розвитку поліграфічних підприємств і видавництв, яка включає три групи індикаторів за основними видами бізнес-процесів.

\section{Список використаної літератури}

1. Пономаренко В. С. Стратегія розвитку підприємства в умовах кризи: монографія / В. С. Пономаренко, О. М. Тридід, М. О. Кизим. Харків: Видавничий Дім «НЖЕК», 2003. 328 с.

2. Раєвнєва О. В. Управління розвитком підприємства: методологія, механізми, моделі: монографія / О. В. Раєвнєва. Харків: Видавничий Дім «HНЕK», 2006. 496 c. 


\section{Система показників оцінки розвитку видавничо-поліграфічних підприємств}

\begin{tabular}{|c|c|c|c|}
\hline \multirow{2}{*}{$\begin{array}{l}\text { Бізнес- } \\
\text { процеси }\end{array}$} & \multirow[b]{2}{*}{ Напрям оцінки } & \multicolumn{2}{|c|}{ Показники } \\
\hline & & $\begin{array}{l}\text { Поліграфічне } \\
\text { підприємство }\end{array}$ & $\begin{array}{c}\text { Видавництво (без } \\
\text { поліграфічної бази) }\end{array}$ \\
\hline \multirow{8}{*}{ Виробничі } & \multirow{5}{*}{$\begin{array}{l}\text { використання } \\
\text { ресурсів }\end{array}$} & \multicolumn{2}{|c|}{ витрати на 1 грн продукції } \\
\hline & & \multicolumn{2}{|c|}{ Фондовіддача } \\
\hline & & \multicolumn{2}{|c|}{ продуктивність праці } \\
\hline & & матеріаловіддача & витратовіддача \\
\hline & & $\begin{array}{c}\text { коефіцієнт використання } \\
\text { виробничої потужності }\end{array}$ & $\begin{array}{c}\text { виробіток в обліково-ви- } \\
\text { давничих аркушах на од- } \\
\text { ного працівника (темп } \\
\text { зростання) }\end{array}$ \\
\hline & тривалість циклу & $\begin{array}{l}\text { середня тривалість } \\
\text { виробничого циклу }\end{array}$ & $\begin{array}{l}\text { середня тривалість } \\
\text { видавничого циклу }\end{array}$ \\
\hline & \multirow{2}{*}{$\begin{array}{c}\text { результатив- } \\
\text { ність основної } \\
\text { діяльності }\end{array}$} & \multicolumn{2}{|c|}{$\begin{array}{c}\text { рентабельність продукції (або рентабельність опе- } \\
\text { раційних витрат) }\end{array}$} \\
\hline & & \multicolumn{2}{|c|}{ рентабельність виробництва } \\
\hline \multirow{11}{*}{ Фінансові } & \multirow{3}{*}{$\begin{array}{l}\text { фінансова } \\
\text { стійкість }\end{array}$} & \multicolumn{2}{|c|}{ коефіцієнт автономії } \\
\hline & & \multicolumn{2}{|c|}{ коефіцієнт мобільності коштів } \\
\hline & & \multicolumn{2}{|c|}{ коефіцієнт фінансової стабільності } \\
\hline & \multirow{3}{*}{ ліквідність } & \multicolumn{2}{|c|}{ коефіцієнт абсолютної ліквідності } \\
\hline & & \multicolumn{2}{|c|}{ коефіцієнт швидкої ліквідності } \\
\hline & & \multicolumn{2}{|c|}{ коефіцієнт покриття } \\
\hline & \multirow{3}{*}{$\begin{array}{c}\text { ділова } \\
\text { активність }\end{array}$} & \multicolumn{2}{|c|}{ коефіцієнт оборотності оборотних коштів } \\
\hline & & \multicolumn{2}{|c|}{ тривалість операційного циклу } \\
\hline & & \multicolumn{2}{|c|}{ тривалість фінансового циклу } \\
\hline & \multirow{2}{*}{$\begin{array}{l}\text { ефективність } \\
\text { діяльності }\end{array}$} & \multicolumn{2}{|c|}{ рентабельність активів } \\
\hline & & \multicolumn{2}{|c|}{ рентабельність власного капіталу } \\
\hline \multirow{6}{*}{$\begin{array}{l}\text { Маркетин- } \\
\text { гові }\end{array}$} & \multirow{2}{*}{$\begin{array}{c}\text { результатив- } \\
\text { ність збутової } \\
\text { діяльності }\end{array}$} & $\begin{array}{l}\text { коефіцієнт відвантаження } \\
\text { готової продукції }\end{array}$ & $\begin{array}{l}\text { коефіцієнт реалізації } \\
\text { готової продукції }\end{array}$ \\
\hline & & \multicolumn{2}{|c|}{ рентабельність продажів } \\
\hline & $\begin{array}{l}\text { ефективність } \\
\text { маркетингових } \\
\text { заходів }\end{array}$ & $\begin{array}{c}\text { коефіцієнт ефективності } \\
\text { реклами і засобів за- } \\
\text { лучення замовників }\end{array}$ & $\begin{array}{c}\text { коефіцієнт ефективності } \\
\text { реклами і засобів } \\
\text { стимулювання збуту }\end{array}$ \\
\hline & \multirow{3}{*}{$\begin{array}{l}\text { конкурентні } \\
\text { переваги }\end{array}$} & \multicolumn{2}{|c|}{ імідж підприємства } \\
\hline & & \multicolumn{2}{|c|}{$\begin{array}{c}\text { частка нових товарів (послуг) в загальному обсязі } \\
\text { продаж (виконуваних робіт) }\end{array}$} \\
\hline & & \multicolumn{2}{|c|}{$\begin{array}{c}\text { частка підприємства на ринку (певному сегменті } \\
\text { ринку) }\end{array}$} \\
\hline
\end{tabular}


3. Швиданенко Г. О. Розвиток підприємства: стратегічні наміри, ризики та ефективність [Електронний ресурс]: колективна монографія / Г. О. Швиданенко, К. С. Бойченко. Київ: KHEУ, 2015. 231 с. URL: http://ir.kneu.edu.ua/bitstream/2010/25228/1/rozvyt pidpryem 15.pdf.

4. Бойченко К. С. Методичний інструментарій оцінювання розвитку підприємства / К. С. Бойченко // Вісник жДтУ. 2014. № 3(69). C. 18-25. URL: http://doi.org/10.26642/ien-2014-3(69)-18-26.

5. Самуляк В. Ю. Групи показників (індикаторів) оцінювання рівня розвитку підприємств / Р. В. Фещур, В. Ю. Самуляк // Вісник Національного університету «Львівська політехніка». Львів: Вид-во Львівська політехніка, 2010. № 691. C. 231-239. URL: https://ena.Ip.edu.ua:8080/handle/ntb/10053.

6. Самуляк В. Ю. Оцінювання рівня розвитку підприємств / В. Ю. Самуляк, Р. В. Фещур // Логістика: Вісник НУ «Львівська політехніка». 2008. № 633. С. 627-636. URL: https://ena.Ip.edu.ua:8080/handle/ntb/631.

7. Погорєлов Ю. С. Оцінювання та моделювання розвитку підприємства: [монографія] / Ю. С. Погорєлов. Луганськ: Глобус, 2010. 512 с.

8. Тимощук М. Р. Планування соціально-економічного розвитку підприємств: [монографія] / [М. Р. Тимощук, О. Є. Кузьмін, Р. Ф. Фещур, Р. В. Шуляр, Н. Ю. Подольчак, І. Б. Олексів]. Київ: УБС НБУ, 2007. 449 с.

9. Жилінська Л. О. Теоретичні аспекти щодо управління розвитком підприємства / Л. О. Жилінська, О. О. Розумчук // Управління економікою: теорія та практика. 2014. № 2014. C. 94-106. URL: https://nbuv.gov.ua/UJRN/ Ue_2014_2014_9.

10. Ефремов Л. И. Стратегия бизнеса. Концепции и методы планирования / Л. И. Ефремов. Москва: Финпресс, 1998. 334 с.

11. Бурмака М. М. Управління розвитком підприємства (на прикладі підприємств будівельної галузі): [монографія] / М. М. Бурмака, Т. М. Бурмака. Харків: ХНАДУ, 2011. 204 с. URL: http://eprints.kname.edu.ua/23548/1.

12. Драган О. І. Управління конкурентоспроможністю підприємств: теоретичні аспекти: монографія / О. І. Драган. Київ: ДАКККіМ, 2006. 144 с.

13. Саєнко М. Г. Стратегія підприємства: підручник / М. Г. Саєнко. Тернопіль: Економічна думка, 2006. 390 с.

14. Тімонін О. М. Оцінка розвитку промислового підприємства: монографія / О. М. Тімонін, К. В. Діхтяренко. Харків: ХНЕУ ім. С. Кузнеця, 2016. 188 c. URL: https://www.repository.hneu.edu.ua/jspui/handle/123456789/16954.

15. Нортон Д. Сбалансированная система показателей. От стратеги к действию / Д. Нортон, Р. Каплан. Москва: Олимп-Бизнес, 2010. 320 с.

\section{References}

1. Ponomarenko, V. S. \& Trydid, O. M. \& Kyzym, M. O. (2003). Stratehiia rozvytku pidpryiemstva $v$ umovakh kryzy. Kharkiv: Vydavnychyi Dim 'INZhEK', 328 p. [in Ukrainian].

2. Raievnieva, O. V. (2006). Upravlinnia rozvytkom pidpryiemstva: metodolohiia, mekhanizmy, modeli. Kharkiv: Vydavnychyi Dim 'INZhEK', 496 p. [in Ukrainian].

3. Shvydanenko, H. O. \& Boichenko, K. S. (2015). Rozvytok pidpryiemstva: stratehichni namiry, ryzyky ta efektyvnist. Kyiv: KNEU, 231 p. Retrieved from http://ir.kneu.edu.ua/bitstream/2010/25228/1/rozvyt_pidpryem_15.pdf [in Ukrainian]. 
4. Boichenko, K. S. (2014). Metodychnyi instrumentarii otsiniuvannia rozvytku pidpryiemstva. Journal of Visnyk ZhDTU, 3(69), 18-25. Retrieved from http://doi.org/10.26642/jen-2014-3(69)-18-26 [in Ukrainian].

5. Feshchur, R. V. \& Samuliak, V. Yu. (2010). Hrupy pokaznykiv (indykatoriv) otsiniuvannia rivnia rozvytku pidpryiemstv. Journal of Visnyk Natsionalnoho universytetu 'Lvivska politekhnika'. Lviv: Vyd-vo Lvivska politekhnika, 691, 231-239. Retrieved from https://ena.lp.edu.ua:8080/handle/ntb/10053 [in Ukrainian].

6. Samuliak, V. Yu. \& Feshchur, R. V. (2008). Otsiniuvannia rivnia rozvytku pidpryiemstv. Journal of Lohistyka: Visnyk NU 'Lvivska politekhnika', 633, 627-636. Retrieved from https://ena.Ip.edu.ua:8080/handle/ntb/631 [in Ukrainian].

7. Pohorielov, Yu. S. (2010). Otsiniuvannia ta modeliuvannia rozvytku pidpryiemstva. Luhansk: Hlobus, 512 p. [in Ukrainian].

8. Tymoshchuk, M. R. \& Kuzmin, O. Ye. \& Feshchur, R. F. \& Shuliar, R. V. \& Podolchak, N. Yu. \& Oleksiv, I. B. (2007). Planuvannia sotsialno-ekonomichnoho rozvytku pidpryiemstv. Kyiv: UBS NBU, 449 p. [in Ukrainian].

9. Zhylinska, L. O. \& Rozumchuk, O. O. (2014). Teoretychni aspekty shchodo upravlinnia rozvytkom pidpryiemstva. Journal of Upravlinnia ekonomikoiu: teoriia ta praktyka, 2014, 94-106. Retrieved from https://nbuv.gov.ua/UJRN/ Ue 201420149 [in Ukrainian].

10. Efremov, L. I. (1998). Strategiya biznesa. Kontseptsii i metody planirovaniya. Moskva: Finpress, 334 p. [in Russian].

11. Burmaka, M. M. \& Burmaka, T. M. (2011). Upravlinnia rozvytkom pidpryiemstva (na prykladi pidpryiemstv budivelnoi haluzi). Kharkiv: KhNADU, 204 p. Retrieved from http://eprints.kname.edu.ua/23548/1 [in Ukrainian].

12. Drahan, O. I. (2006). Upravlinnia konkurentospromozhnistiu pidpryiemstv: teoretychni aspekty. Kyiv: DAKKKiM, 144 p. [in Ukrainian].

13. Saienko, M. H. (2006). Stratehiia pidpryiemstva. Ternopil: Ekonomichna dumka, 390 p. [in Ukrainian].

14. Timonin, O. M. \& Dikhtiarenko, K. V. (2016). Otsinka rozvytku promyslovoho pidpryiemstva. Kharkiv: KhNEU im. S. Kuznetsia, 188 p. Retrieved from https://www.repository.hneu.edu.ua/jspui/handle/123456789/16954 [in Ukrainian].

15. Norton, D. \& Kaplan, R. (2010). Sbalansirovannaya sistema pokazateley. Ot strategi k deystviyu. Moscow: Olimp-Biznes, 320 p. [in Russian].

\section{В статье рассмотрены методы оценки уровня развития предприятий, охарактеризованы группы показателей (индикаторов), которые используются при оценке разви- тия субъектов хозяйствования и сформирована система показателей оценки уровня развития издательско- полиграфических предприятий с учетом отраслевых особенностей.}

Ключевые слова: развитие; оценивание развития; конкурентоспособность; потенциал; индикатор; система показателей; издательско-полиграфические предприятия. 
The article deals with the methods of assessing the level of development of enterprises, the groups of indicators used in assessing the development of business entities are characterized and a system of indicators evaluation of the level of development of publishing and printing companies, is formed taking into account branch features.

Keywords: development; assessment of development; competitiveness; potential; indicator; system of indicators; publishing and printing companies.

Рецензент - Л. П. Шендерівська, канд. екон. наук, доцент, КПІ ім. Ігоря Сікорського 